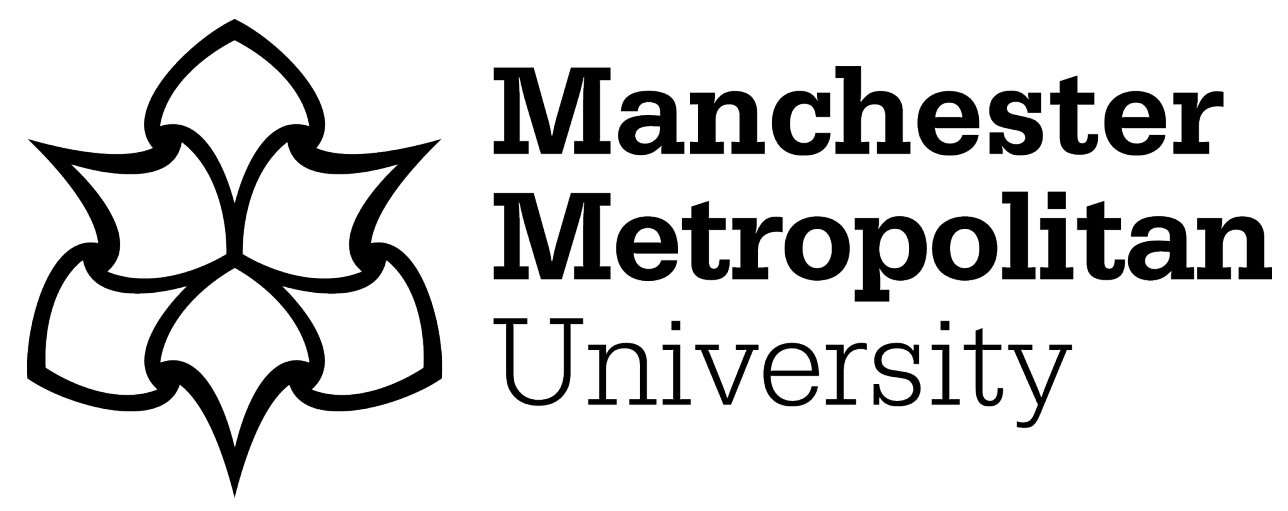

Holmes, Rachel ORCID logoORCID: https://orcid.org/0000-0002-0114-5477 (2020) Performing findings: tales of the theatrical self. In: Handbook of Qualitative Research in Education. Edward Elgar. ISBN 9781788977142

Downloaded from: https://e-space.mmu.ac.uk/626686/

Version: Accepted Version

Publisher: Edward Elgar

DOI: https://doi.org/10.4337/9781788977159

Please cite the published version 


\section{Performing findings: tales of the theatrical self Rachel Holmes}

\section{INTRODUCTION}

This chapter offers a brief overview of aspects of critical, performance and surrealist ethnography as ways to represent research findings. It evokes performances amongst the written-ness of (con)text and the challenges of classroom encounters as they each become entangled together as expressions of findings. It puts moments of 'data' to work as I try to interrupt my more familiar classroom performances of 'self', by turning to data in the form of narratives to provoke 'ontological stammering' (Lather, 1998, p.495). Using and writing through a story of a classroom encounter as an integral component of reflexive ethnography, attempts are made to perform some of my growing uncomfortable-ness as a teacher within this higher education landscape.

\section{CRITICAL, PERFORMANCE AND SURREALIST ETHNOGRAPHY}

According to Haseman (2006, p. 299), 'the stark and abiding difference between quantitative and qualitative research lies in the way that research findings are expressed. Quantitative research is 'the activity or operation of expressing something as a quantity or amount - for example, in numbers, graphs or formulas' (Schwandt, 2001, p. 215). However, qualitative research, with its concern to capture the observed, interpreted and nuanced properties of behaviours, responses and things refers to 'all forms of social inquiry that rely primarily on ... nonnumeric data in the form of words' (Schwandt, 2001, p. 213). However, even within the qualitative genre, there is increasing variation and innovation in the ways research findings are gathered, thought about and expressed. Hayano (1979) argues that as anthropologists moved out of the colonial era of ethnography (Atkinson, Chapter 38, this volume), they would begin to study the social worlds and subcultures of which they were a part: 'Self-reflexivity_. . . in the ethnographic process, alongside the crisis in ethnography and the "linguistic" and 
"cultural turn" in socio-cultural theory_has led to demands for experimentation in the representation of ethnographic data' (O'Neill, 2002, p. 71). More latterly St Pierre (2011, 2013; Lather \& St Pierre, 2013) complicate the notion of representation further, reflecting on the "ontological turn" and its implications for a post-qualitative inquiry that others call, "the "new empiricism" (for example see Clough, 2009) and the "new materialism" (for e.g. see Alaimo \& Hekman, 2008; Barad, 2007; Coole \& Frost, 2010; Mol, 2002)". The ontological turn, as Deleuze and Guattari explain, refuses any material/textual distinction, "There is no longer a tripartite division between a field of reality (the world) and a field of representation (the book) and a field of subjectivity (the author)" (1980/1987, p. 23).

The increasingly prevalent body of ethnographic educational research including, for example, Devine (1996), Fine (1994), Paley (1992) and Ayers (1997) continues to explore alternative 'readings' of the social world, as 'methodologically speaking, the construction and reproduction of ethnographic print-based texts has in the main conformed to a particular set of traditional conventions' (O'Neill, 2002, p. 70). Due to its traditional conformity, Quantz (1992) believes there is some sense of the field being in a state of creative disarray. Denzin and Lincoln (2000) describe a growing crisis of representation illustrated through seven historical 'moments' where qualitative researchers have begun to imagine and produce new forms of their work. The current (seventh) moment in the twenty-first century is 'the methodologically contested present' (Denzin and Lincoln, 2005 , p. 1116), a time of tension between quantitative and qualitative researchers, and more specifically, a time when qualitative researchers are exploring varied methodologies, paradigms and perspectives for their inquiries. Denzin (1997) and Atkinson and Coffey (1995) propose that this crisis of representation in anthropology is paralleled by an increasing debate and scrutiny of ethnographic texts questioning their intellectual status within sociology and the ways in which they claim to represent cultural phenomena. Quantz (1992) suggests that ethnography should continue to participate in a larger 'critical' dialogue rather than exclusively follow any particular set of methods or research techniques and Genet writes, 'Nothing will prevent me, neither close attention nor the desire to be exact, from writing words that sing' (1993, p. 59), which suggests the need to embrace, rather than deny ever-more inclusive, creative and eclectic approaches to ethnography. Haseman (2006) insists that research outputs and claims to knowing must be made through the symbolic language and forms of their practice, suggesting that 'data works performatively. It not only expresses the research, but in that expression becomes the research itself' (p. 101). In other areas of the social sciences such as human geography (Anderson, 2010), philosophy (Barad, 2007; Dolphijn, and van der Tuin, 2012) and social anthropology (Ingold, 2011), the notion of non-representational theory has taken hold, "non-representational theory concerns itself with practice, action, and performance... suspicious of all attempts to uncover symbolic meaning where other, more practical forms of meaning or even no meaning at all exists" (Vannini et al., 2014, p. 4)

According to Vannini et al. (2014), non-representational theory is now "widely 
considered to be the successor of postmodern theory, the logical development of post-structuralist thought, and the most notable intellectual force behind the turn away from cognition, symbolic meaning, and textuality" (p. 2).

This move towards creativity and innovation in relation to (non) represen- tation and the need to recognize findings that emerge from a diversity of research contexts and practices proposes that in undertaking critical ethnography, researchers aim 'to move people to see themselves and their relation to a particular set of circumstances differently' (Pignatelli, 1998,_p. 416). One way of doing this is to assemble and juxtaposition texts that emanate from diverse genres of writing and other modes of representa- tion, drawing on Clifford's exploration of ethnography and surrealism to examine the play between the familiar and the strange, that moment in which the possibility of comparison exists in unmediated tension with sheer incongruity... the cuts and sutures of the research process are left visible: there is no smoothing over or bending of the work's raw 'data' into a homogeneous representation ... as well as ... data not fully integrated within the work's governing interpretation. ... (Clifford, 1981, p. 563).

This incongruity, unexpectedness and juxtapositioning of the familiar with the strange, or the familiar finding some way to become strange to, and in itself, is suggestive that there may be opportunities for the 'roughly textured, choppy ... less seamless narration ...'(Pignatelli, 1998, p. 419) within the ethnographic 'text(s)' to argue with itself. Referring to Derrida, Cornell takes up the themes of attacking the familiar, of interruption and the unexpected in discussing ways to represent the Other in the ethnographic text, "The auratic gaze defies the organization of looking as a form of mastery ... The Other is allowed to be in her distance precisely so that she can look back' (Cornell, 1992, p. 77). 


\section{Handbook of qualitative research in education}

A method of ethnography drawing on juxtapositioning of (con)texts and growing out of cross-disciplinary work in sociology, anthropology, communication studies, performance arts and cultural studies is performance (auto)ethnography, often understood to lie within the field of qualitative research. According to Denzin (2003), performance (auto) ethnography is a genre within critical, postmodern ethnography, a variation on what Paget (1990) calls ethnoperformance, what Mienczakowski (1995) calls ethnodrama or ethnotheatre, what Glass (2001) makes reference to as critical performance pedagogy, what Giroux (2000) discusses amongst performative cultural politics, what Fine cited in Denzin and Lincoln, 2003 calls participatory performance action inquiry and what Turner (1982) calls reflexive anthropology. According to Charmaz (2006), early performance ethnography began to integrate autobiography with ethnography, self-observation in ethnographic research that necessarily attended to the worlds in which ethnographers were participating. In other words, attending to the all-too-familiar in an attempt to render strange. Smith and Gallo (2007) discuss an interesting historical version of the development of 'performance' in art history, sociology and anthropology, drawing on the work of Turner (1982), Geertz (1995) and Goffman (1974). They then take these early theories of performance and combine them with ethnographic research, drawing on the work of contemporary social scientists such as Conquergood (2002), Denzin (1997, 2003), Madison (1998) and Madison and Hamera (2006). Smith and Gallo suggest that often performance ethnography is presented as a performance text that one or more people write and read for an audience. The material on which the text is based can be autobiographical stories, ethnographic field notes, reflexive journal entries or specific memories of a life event (Smith and Gallo, 2007, 
p. 521). The purpose of the text is to engage the audience fully, so that performer and listener meet in the liminal (or threshold) space that lies between them p. 522).

Returning to Denzin and Lincoln (2005), the driving force of the current qualitative focus is towards more feminist, ethical, communitarian, democratic, engaged, performative and social justice-oriented research. Pollock (2006) writes, 'the object of ethnography has . . . shifted the relationship of the researcher and the ostensibly "researched" (the field and field subjects), reconfiguring longstanding subject-object relations as co-performative' (p. 326). There are numerous literal responses to ethnographic 'texts' being re-presented through performance. For example O'Neill (2002) discusses a project that uses video and live art performance as a response to transcripts of interviews with women working as prostitutes and fuses dance, text, sound and video. She reflects on how the re-presentation of ethnographic data in artistic form can access 'a richer understanding of the complexities of lived experiences ... and reach beyond academic communities (p. 70).

With the idea of 'lived experiences' in mind, Clifford (2002) discusses the notion of ethnographic surrealism, whereby an approach 'cuts across retrospectively established definitions . . . to recapture . . . a situation in which ethnography is again something unfamiliar and surrealism not yet a bounded province of modern art or literature . . genres do not remain firmly anchored' (pp. 117-18). He suggests that 'ethnographic surrealism is a statement about past and future possibilities for cultural analysis' ( $p$. 119). Similarly within critical and performance ethnography, de-stabilized approaches to ways 'lived experiences' are being re-presented are recognized. This chapter will draw eclectically from developments within these fields in an effort to mobilize ideas around fragmentation, juxtapositioning and incompleteness as the complexities of lived experiences in the classroom as a teacher-researcher are explored.

My interest here lies in the potential of the university classroom as (con)text and the students as active audience or co-subjects that enable pedagogical performances where reflexive ethnography finds itself being negotiated, 'a pedagogical borderland, in the spaces where rhetoric, politics, parody, pastiche, performance, ethnography and critical cultural studies come together' (Conquergood, 1992, p. 80). I would argue for the university classroom as an act of immersive ethnography in which,

contrary to the hidden 'I' of allegedly objective recording; or the deferential 'I' apparently standing fixed . . . the self-subject of the researcher is immersed in the co-subject, entangled with, even ravished by the co-creative process such that the subjectivity of the researcher is diffused within, even to the point of disappearing into, the field's body. Accordingly, we no longer see the scholar 
'I' at work but we certainly feel her passion, his grace. . . (Pollock, 2006, p. 326)

The university classroom seems to be an interesting context for co-subjects (teacher and students) to become entangled in the unfolding pedagogy of performance. I turn now to the university teacher as a writer of that performative (con)text.

\section{TEACHER AS A WRITER, WRITER AS A TEACHER: THE CLASSROOM ENCOUNTER}

Within the diverse context of the university classroom, I 'find' myself becoming increasingly uncomfortable as a teacher, contributing to the mistaken stability of the cultural and structural relationships that characterize a particular version of western-style education. This is particularly pertinent for me as I work with students on undergraduate degrees in childhood studies who will themselves go on to work with children. I believe that in their 'preparation' for work with children, students need to be challenged to engage with complex constructions of the child, become mindful of the ways in which political systems affect these constructions and how they impact upon the work they will go on to do in different early years' contexts. For students, this requires them to think and talk critically about the process of education and schooling and to go on to act on ideas that disrupt the re-production of legitimized and privileged forms of knowledge. However, this poses particular tensions for me as a white, female teacher, constructed as part of a system that seems to legitimize and privilege certain forms of knowledge. These mistakenly stable notions of 'knowledge' lie amongst unstable and always shifting and diverse cultural, racial and religious classroom 'realities' within which as a teacher, I aspire to foster students' criticality. To unpack some of these tensions, I intend to reflect upon one of the many narratives I have written during my (life) time as a teacher that probe the intricacies of teacher-student encounters. This narrative will be used to explore how, as a teacher-researcher, I am able to disturb my understandings of 'performances' within a classroom encounter, by moving towards writing an 'incomplete frame' (Stronach, 1996, p. 365) that otherwise might 'enclose' particular understandings of myself as a teacher, and of students.

The session I am about to reflect upon was part of a series of units called 'Explorations', which provide an integrating mechanism at each level of the degree programme for studying the different ways in which children and their families have been and continue to be understood. 
The aim within these units is to explore ways to deconstruct narratives and visually symbolic representations of the child and to facilitate the students' reframing of deeply embedded concepts and understandings. In Explorations sessions, I often use film, photographs and documentary so that previously 'known' texts are disturbed and students might engage in discussions that question the ways they 'know' these texts. I introduced this particular classroom session by talking to students about my uneasiness with being a white female teacher, about to discuss and 'teach' aspects of race, culture and religion to a mixed racial and cultural group of undergraduate students.

The classroom, Tuesday morning. I asked the students to consider why they thought the Asian community was 'absented' in this documentary (Last white kids, Thompson, 2003) and in response, a white student suggested that the Asian voice was not represented because 'most Asian women would stay at home' and would not have 'good enough command of the English language' to talk to the documentary-makers. A British-Kashmiri student immediately responded, suggesting this was a 'ridiculous stereotype' and an 'offensive misunderstanding' of Asian families and particularly Asian women. She seemed agitated and angry towards the white student, who seemed to respond in what I perceived as a defensive way. At this point, I began to feel uncomfortable, conscious that I wanted all students to be able to express themselves, but mindful that the emotionality swirling between students seemed to be moving them towards a confrontation. A further comment came from the British-Kashmiri student who suggested that, as a white teacher I should not allow the 'Asian' community to be constructed as an all-encompassing homogeneity, but rather as differentiated Pakistani, Bangladeshi and Indian families within the community. I felt 'interrupted'. This interruption to my habitual performance as 'teacher' rendered me feeling vulnerable in the classroom, a place where I do not usually feel inadequate. (Journal extract, 2005)

My intention here is to develop an ever more complex story of 'performing findings' as a 'theatre of the self' (Cavarero, 2000, p. 34), interrupted and problematized by co-subjects that enables pedagogical performances where reflexive ethnography finds itself being negotiated. The literature that opened this chapter establishes an ever-changing theoretical and methodological context, put to work here as a documented series of interwoven texts. Shifting between author, spectator, reader and editor of these texts, I become a storyteller, telling a story about other stories and reader, reading myself as a storyteller. Latterly, I have introduced the classroom encounter (that in and of itself draws from a plethora of other labyrinthine autobiographical stories), lying within a broader and intricate methodological story that is 'Chapter 42 Performing findings: tales of the theatrical self'. The classroom encounter becomes a context for self-interrogation where I attempt to evoke co-subjects in a co-performance of findings. 
Different characters become 'the necessary others' (Cavarero, 2000, p. 88), portrayed as storytellers themselves. I want to consider what I can learn about myself (as a teacher) in relationship with those 'necessary others' as I engage in telling stories about those storytellers.

What strikes me about this classroom story is the infestation of barely written, barely formed and dimly glimpsed sensations (MacLure et al., 2010, p. 2; Holmes, 2013, p. 358; Holmes 2014, p. 782; Holmes 2015, p. 6) that nevertheless constitute an overwhelming odour of emotional discomfort. Writers such as Jackson and Mazzei (2008), St Pierre and Roulston (2006), MacLure (2011, 2012), Lather (2013), Gorard and Symonds (2010) and Saldaña (2003), amongst many others discuss (in)articulated moments for example silences, insider/outsider researcher, sighs, snorts, stuck places, laughter and shrugs where data defies representation, resists identity. Documenting the students as necessary others, I sense an attack on the familiar, of interruption and the unexpected, where jolts and emotional ruptures rendered me (mis)recognized, appearing to myself by way of 'the gaze of others' (Arendt, 1958 [1977], cited in Brightman, 1995, p. 294). Perhaps this sense of (mis)recognition could be reconceptualized as 'mimicry', which 'must continually produce its slippage . . . Mimicry is at once resemblance and menace' (Bhabha, 1994, p. 86). Were these moments of me, the classroom, the students, the teaching/learning encounter being familiar but made strange? Despite opening this session with a confessional introduction to my own vulnerabilities, limits to my interpretations, understandings, trying to summon autobiographical data that would help students (and myself) situate my own racial struggles, I still seem to have be striving to remain camouflaged (familiar) as a woman, as a teacher, yet menaced (made strange) by the ruptures, the emotional slippages that seemed to infest the classroom encounter.

\section{DEMOCRATIC DIALOGUES(?)}

The student who made reference to me as a 'white teacher' presents a particular moment of recognition. As the 'teacher' (resemblance), the student seemed to express her expectations of me to confront the emotional and racially motivated struggles within the classroom. However, as 'white' (menace), perhaps she was not surprised, but nevertheless troubled that I did not disturb homogenizing tendencies and reductive critiques embedded within the classroom discussions. In this example, despite my introductory proclamations that I saw myself as white, something menacing around my 'practices' of being a 'white' teacher ruptured the classroom discourse. Drawing on media studies, literary theory and the work of psychoanalytical feminism, Ellsworth describes 'coming up against stuck place after stuck place' (1997, p. xi) as a way to keep moving with 'the impossibility of teaching' (p. 9), perhaps Lather's 'ontological stammering' (1998, p. 495), a critical performance pedagogy, where we learn from

ruptures, failures, breaks and refusals. With the students as co-subjects, audience, actors and storytellers in the classroom encounter and me as 
teacher-researcher-performer, I can begin to think about this narrative as stuck place after stuck place, a stammering rupture to my usual 'stylized repetition of [classroom] acts' (Butler, 1990, p. 40).

In order to re-consider ways I might look upon my emotionality as entangled within my stammering 'performances as teacher' in the classroom encounter, I turn to Lorde (1984, p. 63) who links the conceptual and political work of confronting racism with the capacity to be angry and to tolerate and use anger. Perhaps this potentially provocative relationship between my own ontological stammer(ing), the sharp jolts of classroom emotions amongst discussions of culture and race are usually tamed, 'some forms of multiculturalism are closely bound up with efforts to . . . cultivate a particular sort of civility' (Mayo, 2001, p. 78). Mayo suggests that the discourse of civility asserts that teachers and students ought to be respectful and tolerant of everyone, which serves to neglect aspects of emotionality that appear to be in and of themselves uncivil or distasteful. This suggests there is a 'civil' discussion to be had, one in which everyone in their tolerance wants to know and be known, wants to understand and to be understood. Gillborn is similarly concerned about exclusionary practices that 'operate beneath a veneer of professed tolerance and diversity' (2006, p. 11), whereby de-politicized language 'is evacuated of all critical content' (p. 16). McIntyre finds difficulty 'understanding the chasm that exists between their [educators] antiracist ideals and their tendency to appropriate long-standing strategies for teaching that benefit the dominant group' (1997, p. 132). Gillborn and McIntyre's uses of terms such as 'chasm' and 'veneer' lead me back to Clifford's notions of scissions and sutures (1981), here the procurement of procedures that divide, then work hard to restore, always incapable of disguising the invasive praxis of restoration. I wonder how my usual classroom practices become alltoo-familiar and accomplished processes of cutting into the student group with a 'white hegemonic gaze' and subverting anti-racist ideals to disguise the workings of colonial restoration, subversive conformity and imperial cultural workings? Sara Ahmed advocates being a 'feminist killjoy' (2010) by naming and calling attention to problems, whereby you become "... the object of shared disapproval, those glances that can cut you up, cut you out". However a 'civil' discussion is suggestive of what Berlak (2005, p. 143) describes as a 'democratic dialogue' which could be understood to foster a form of repetition that stabilizes the common wisdom. However, it might also function to suppress strong emotions and confrontation in the classroom. According to bell hooks (1994), dialogue is often confined to the standards of acceptable bourgeois decorum, which operates to undermine constructive forms of confrontation and conflict that emerge from intense, and often aversive, responses.

My worries around these issues are that this democratic tolerance and respectfulness is tainted by what Jones (cited in Lather, 1998) claims is a cannibal desire to know the other through being fed by her. Lather (1998) 
suggests that there is a voyeuristic refusal at work, one which refuses to know that the Other may not want to be known. This classroom encounter has pushed me to contemplate Lather's ideas, but also contemplate that the Other may not have a choice, but may find herself assuming to be known in particular and reductive ways.

In the classroom story by constituting something of my white, western identity as a teacher, was I denying the presence of voices who might disrupt the comfort of certain absences? Given my own cultural practices and the discursive discourses that swirl amongst dominant white narratives of race, did I police what I thought was appropriate for the classroom and by doing so, collude with the white student, failing to interrupt her constructions of all non-white families as 'Asian'? The British-Kashmiri student took the opportunity to disrupt my habitual 'performances' as teacher in her challenges to the ways I was 'performing' being white and being unemotional around what could be described as emotive issues of race.

\section{FOOTNOTES}

This chapter has begun to disturb ways I understand particular 'performances' of myself as teacher and of 'findings' within reflexive inquiry, where stories of emotionality and race were juxtaposed with an assumed professional competence that classroom encounters are based on straightforward liberal-humanist practices embodied by the teacher-self. It has shifted any sense of comfortable-ness around the teacher (actor)-student (audience), as well as student-student relationships. The idea of students as co-subjects becomes an opportunity to embrace ideas around a 'fertile space .. . producing bafflement' (Lather, 2004, p. 2), but also becomes a much more dangerous space as I interrogate 'performances of self' alongside difficult issues, de-stabilizing and politicizing taken-for-granted 'knowledges' about self and other. If I recognize that dominant regimes of truth (Foucault, 1977) cannot be left undisturbed, and that a move to 'democratic dialogue' can serve to reinscribe particular absences, then how uncomfortable or 'uncivil' should it become in the classroom? How could I perceive and regulate the boundaries around acceptable and unacceptable emotionality in different, less 'enclosed' ways without constraining emotional engagement and expression? Minha-ha Trinh (1989) suggests that we need to 'practice ways of reading and writing, speaking and listening, in which one's authority comes from one's ability to confront one's own privileges rather than to merely confront the privileges of others' ( $p$. 193). If I perceive my 'whiteness' as a privilege, then I must consider the painful and lingering work of exposure, together with the difficult notion 
of declaration as the 'admission', which 'itself becomes seen as good practice' (Ahmed, 2004, p. 71). I would want to encourage students and myself to be challenged by our mutually critical, albeit stammering gazes that obstruct and resist our comfortableness as these moments could provoke both students and myself to re-think our assumptions about ourselves and each other.

With reference to performing findings within teacher research, reflecting upon a classroom narrative as particular 'performance of findings' enabled me to find my 'self' juxtaposed with students as the 'necessary others' (Caverero, 2000, p. 8). This shifting process of self- and otherrepresentation seems to have dislocated my understandings of myself from 'enclosed' conceptual positionings and I now find myself entangled amongst Derrida's 'folding back' process (1981, p. 104), using writing as a process of 'dis-covering' (p. 154), where the text becomes a tissue, a web or a tapestry. I find possibilities within what Derrida (1981, p. 83) describes as 'the same tissue, within the same texts, we will draw on other filial filaments, pull the same strings once more, and witness the weaving or unraveling of other designs'. This chapter has allowed me space to speak within particular discursive practices about things not generally spoken of, or only spoken of in particular ways before. For example, I feel that my teacher-researcher role has begun to be re-imagined as I re-consider the emotional character of the deeply interwoven teaching and research processes where 'emotional matters belong to the researcher at least as much as the researched' (Burman, 1998, p. 14).

\section{REFERENCES}

Ahmed, S. (2004), 'Declarations of whiteness: the non-performativity of anti-racism', Borderlands E-Journal 3 (2), 69-84.

Ahmed, S. (2010). 'Feminist Killjoys (And Other Willful Subjects)'. The Scholar and Feminist Online. Issue 8.3: Summer 2010, accessed 3.10.18 at http://sfonline.barnard.edu/polyphonic/print ahmed.htm).

Alaimo, S. \& Hekman, S. (Eds.). (2008). Material feminisms. Bloomington, IN: Indiana University Press.

Anderson, B. (2010). Taking-Place: Non-Representational Theories and Geography. Oxon: Routledge

Arendt, H. ([1958]1977), The Human Condition, Chicago, IL: University of Chicago Press.

Atkinson, P. and Coffey, A. (1995), 'Realism and its discontents: on the crisis of cultural representation in ethnographic texts', in B. Adam and S. Allan (eds), Theorizing Culture. An Interdisciplinary Critique After Postmodernism, London: UCL Press.

Ayers, W. (1997), A Kind and Just Parent: The Children of Juvenile Court, Boston, MA: Beacon Press.

Barad, K. (2007). Meeting the universe halfway: Quantum physics and the entanglement of matter and meaning. Durham, NC: Duke University Press.

Berlak, A.C. (2005), 'Confrontation and pedagogy: cultural secrets, trauma, and emotion in antioppressive pedagogies', in M. Boler(ed.), Democratic Dialogue in Education: Troubling Speech, Disturbing Silence, New York: Peter Lang, pp. 123-44.

Bhabha, H. (1994), The Location of Culture, New York: Routledge.

Brightman, C. (1995), Between Friends: The Correspondence of Hannah Arendt and Mary McCarthy 1949-1975, New York: Harcourt Brace.

Burman, E. (1998), 'Engendering developments', Professorial inaugural lecture paper presented in Manchester Metropolitan University, 8 October.

Butler, J. (1990), Gender Trouble: Feminism and the Subversion of Identity, New York: Routledge. 
Cavarero, A. (2000), Relating Narratives: Storytelling and Selfhood, London: Routledge.

Charmaz, K. (2006), 'The power of names', Journal of Contemporary Ethnography, 35 (4), 396-9.

Clifford, J. (1981), 'On ethnographic surrealism', Comparative Studies in Society and History, 23, 539-64.

Clifford, J. (2002) The Predicament of Culture: Twentieth-century Ethnography, Literature, and Art, Cambridge, MA: Harvard University Press.

Clough, P.T. (2009). The new empiricism: Affect and sociological method. European Journal of Social Theory, 12(1): 43-61.

Conquergood, D. (1992), 'Ethnography, rhetoric and performance', Quarterly Journal of Speech, 78, 80-97.

Conquergood, D. (2002), 'Performance studies: interventions and radical research' The Drama Review, 46, 145-53.

Coole, D. \& Frost, S. (Eds.). (2010). New materialisms: Ontology, agency, and politics. Durham, NC: Duke University Press.

Cornell, D. (1992), The Philosophy of the Limit, New York: Routledge.

Deleuze, G. \& Guattari, F. (1987). A thousand plateaus: Capitalism and schizophrenia. (B. Massumi, Trans.). Minneapolis, MN: University of Minnesota Press. (Original work published 1980).

Denzin, N. (1997), Interpretative Ethnography: Ethnographic Practices for the 21 st Century, London: Sage.

Denzin, N.K. (2003), 'Performing [Auto] ethnography politically', Review of Education, Pedagogy, and Cultural Studies, 25 (3), 257-78.

Denzin, N.K. and Lincoln, Y.S. (eds) (2000), Handbook of Qualitative Research, 2nd edn, London: Sage.

Denzin, N.K. and Lincoln, Y.S. (eds) (2003), The Landscape of Qualitative Research, London: Sage.

Denzin, N.K. and Lincoln, Y.S. (eds) (2005), The Sage Handbook of Qualitative Research, 3rd edn, London: Sage.

Derrida, J. (1981), Dissemination, trans. B. Johnson, Chicago, IL: University of Chicago Press.

Devine, J. (1996), Maximum Security: The Culture of Violence in Inner-city Schools, Chicago, IL: University of Chicago Press.

Dolphijn, R. and van der Tuin, I. (2012). New Materialism: Interviews \& Cartographies. Michigan, Open Humanities Press

Ellsworth, E. (1997), Teaching Positions: Difference, Pedagogy and the Power of Address, New York: Teachers College Press.

Fine, M. (1994), 'Working the hyphens: reinventing self and other in qualitative research', in N.K. Denzin and Y.S. Lincoln (eds), Handbook of Qualitative Research, Thousand Oaks, CA: Sage, pp. 70-82.

Foucault, M. (1977), Discipline and Punish, London: Penguin.

Geertz, C. (1995), After the Fact: Two Countries, Four Decades, One Anthropologist, Cambridge, MA: Harvard University Press.

Genet, J. (1993), 'Miracle of the rose' in E. White (ed.), The Selected Writings of Jean Genet, Hopewell, NJ: The Ecco Press, pp. 52-68.

Gillborn, D. (2006), 'Critical race theory and education: racism and anti-racism in educational theory and praxis', Discourse, 27 (1), 11-32.

Giroux, H. (2000), Impure Acts: The Practical Politics of Cultural Studies, New York: Routledge.

Glass, R.D. (2001), 'On Paulo Freire's philosophy of praxis and the foundations of liberation education', Educational Reseacher, 30, 15-25.

Goffman, E. (1974), Frame Analysis, Harmondsworth: Penguin Books.

Gorard, S. and Symonds, J. (2010) 'Death of mixed methods?: Or the rebirth of research as a craft'. Evaluation and Research in Education, 236 (2). pp. 121-136.

Haseman, B. (2006), 'A manifesto for performative research', Media International Australia Incorporating Culture and Policy, 118, 98-106.

Hayano, D. (1979), 'Auto-ethnography: paradigms, problems, and prospects', Human Organization, 38, 99-104.

Holmes, R., Jones, L. and Osgood, J. (2018). 'Mundane habits, ordinary affects and methodological creations'. In A. Cutter-Mackenzie, K. Malone and E. Barratt Hacking (Eds) (2018). International Research Handbook on ChildhoodNature: Assemblages of Childhood and Nature Research. UK: Springer.

Holmes, R. (2015). 'My tongue on your theory: the bittersweet reminder of every-thing unnameable'. Discourse: Studies in the Cultural Politics of Education, 37(5), PP. 662 - 679. Special issue 'Fabulous monsters: alternative discourses of childhood in education', guest 
editors, R. Holmes, L. Jones \& M. MacLure.

Holmes, R. (2014). 'Fresh Kills: to (de)compose data'. Qualitative Inquiry. Special Issue

'Analysis After Coding in Qualitative Inquiry'. Guest co-editors Elizabeth St Pierre and Alicia Jackson, Qualitative Inquiry, 20 (6), pp. 784-792.

hooks, b. (1994), 'Confronting class in the classroom', In b. hooks (ed.), Teaching to Transgress, New York: Routledge, pp. 77-92.

Ingold. T. (2011). Being Alive Essays on movement, knowledge and description. Oxon: Routledge Jackson, A.Y. and Mazzei, L. (eds) (2008). Voice in Qualitative Inquiry: Challenging conventional, interpretive, and critical conceptions in qualitative research. London: Routledge.

Lather, P. (1997), 'Drawing the line at angels: working the ruins of feminist ethnography', International Journal of Qualitative Studies in Education, 10 (3), 285-304.

Lather, P. (1998), 'Critical pedagogy and its complicities: a praxis of stuck places', Educational Theory, 48 (4), 487-97.

Lather, P. (2004), 'Getting lost: feminist efforts toward a double(d) science', Paper presented at the AREA, San Diego, California, 12-16, April, available at http://www.petajwhite. net/Uni/910/Legit\%20and\%20Representation/Representation\%20Precis/lather\%20Getting \%20lost.pdf (accessed 18 March 2011).

Lather, P. (2013) Methodology -21: What Do We Do in the Afterward? Qualitative Studies in Education, 26(6), 634-645.

Lather, P. \& St.Pierre, E.A. (2013). Post qualitative research. International Journal of Qualitative Studies in Education, 26(6), 629-633.

Lorde, A. (1984), Sister Outsider: Essays and Speeches, The Crossing Press feminist series, Trumansburg, NY: Crossing Press.

MacLure, M., Holmes, R., MacRae, C. and Jones, L. (2010), 'Animating classroom ethnog- raphy: overcoming video-fear', International Journal of Qualitative Studies in Education. First published on 29 April 2010 (iFirst).

MacLure, M. (2011). 'Qualitative Inquiry: Where Are the Ruins?. Qualitative Inquiry, Volume 17 (10), pp. $997-1005$.

MacLure, M. (2012). 'Classification or wonder? Coding as an analytic practice in qualitative research', in B. Coleman and J. Ringrose (eds) Deleuze and Research Methodologies. Edinburgh: Edinburgh University Press, forthcoming 2012.

Madison, D.S. (1998), 'Performances, personal narratives, and the politics of possibility', in Sheron J. Dailey (ed.), The Future of Performance Studies: Visions and Revisions, Annadale, VA: National Communication Association, pp. 276-86.

Madison, D.S. and Hamera, J. (eds) (2006), The Sage Handbook of Performance Studies, Thousand Oaks, CA: Sage.

Mayo, C. (2001), 'Civility and its discontents: sexuality, race, and the lure of beautiful manners', Philosophy of Education 2001, 78-87.

McIntyre, A. (1997), Making Meaning of Whiteness: Exploring Racial Identity with White Teachers, New York: State University of New York Press.

McIntyre, A. (2002) 'Exploring whiteness and multicultural education with prospective teachers', Curriculum Inquiry, 32 (1), 31-49.

Mienczakowski, J. (1995), 'The theater of ethnography: the reconstruction of ethnography into theater with emancipatory potential', Qualitative Enquiry, 1 (3), 36075 .

Minha-ha Trinh, T. (1989), Woman, Native, Other: Writing Postcoloniality and Feminism, Bloomington, IN: Indiana University Press.

Mol, A. (2002). The body multiple: Ontology in medical practice. Durham, NC: Duke University Press.

O’Neill, M. (2002), 'Renewed methodologies for social research: ethno-mimesis as perform- ance praxis', The Sociological Review, 50 (1), 69-88.

Paget, M. (1990), 'Performing the text', Journal of Contemporary Ethnography, 19, 136-55.

Paley, V.G. (1992), You Can't Say You Can't Play, Cambridge, MA: Harvard University Press.

Pignatelli, F. (1998), 'Critical ethnography/poststructuralist concerns: Foucault and the play of memory', Interchange, 294, 403-23.

Pollock, D. (2006), 'Marking new directions in performance ethnography', Text and Performance Quarterly, 26(4),325-9.

Quantz, R.A. (1992), 'On critical ethnography (with some postmodern considerations)', in M.D. LeCompte, W.L. Milroy and J. Preissle (eds), The Handbook of Qualitative Research in Education, San Diego, CA: Academic Press, pp. 447-506.

Saldaña, J. (2003). 'Dramatizing Data: A Primer'. Qualitative Inquiry, Volume 9 (2), pp. 218 - 236. Schwandt, T.A. (2001), Dictionary of Qualitative Research, Thousand Oaks, CA: Sage. Smith, C.A.M. and Gallo, A.M. (2007), 'Applications of performance ethnography in nursing', Qualitative Health Research, 17 (4), 521-8. 
St. Pierre, E. and Roulston, K. (2006). The state of qualitative inquiry: a contested science. International Journal of Qualitative Studies in Education, 19 (6), pp. 673 - 684.

St.Pierre, E.A. (2011) Post qualitative research: The critique and the coming after. In N.K. Denzin \& Y.S. Lincoln (Eds.). Sage Handbook of Qualitative Inquiry (4 ${ }^{T H}$ edition) ( $p p .611$ 635). Los Angeles, CA: Sage.

St.Pierre, E.A. (2013). The posts continue: Becoming. International Journal of Qualitative Studies in Education, 26(6), 646-657

Stronach, I. (1996), 'Fashioning post-modernism: tales from the fitting room', British Education Research Journal, 22 (3), 359-75.

Thompson, S. (2003), Cutting Edge: The Last White Kids, Channel Four, 30 October.

Turner, V. (1982), 'Performing ethnography', The Drama Review, 26, (2), 33-50.

Vannini, P., \& Taggart, J. (2014). Off the grid: Re-assembling domestic life. New York, NY: Routledge 